Área Abierta. Revista de comunicación audiovisual y publicitaria

ISSN: 2530-7592 / ISSNe: 1578-8393

\title{
Epistolarity, Voice, and Reconciliation in Recent North African Documentaries $^{1}$
}

\author{
Sheila Petty ${ }^{2}$
}

Submitted: 05th September 2019 / Approved: 26th October 2019

\begin{abstract}
This essay takes as its starting point Laura Rascaroli's notion of "epistolarity as argumentation" to probe how North African filmmakers Habiba Djahnine, Drifa Mezenner, and Jawad Rhalib deploy the letter in their documentary films as a strategy to come to terms with personal alienation at a specific point in their national histories. In Letter to my Sister (2006), I Lived in the Absence Twice (2011) and The Turtles'Song: a Moroccan Revolution (2013), working within reflexive and performative modes of documentary, the filmmakers become protagonists of their own projects and find their personal voice after years of repression or exile. Thus, they ultimately connect their voice with others of the nation as strategy of reconciliation. The essay argues that these first-person documentaries use the epistolary device to allow the filmmakers to rediscover their own voices and place within their own national histories of Algeria and Morocco.
\end{abstract}

Key words: documentary; epistolarity; reflexivity; performativity; voice; argumentation

\section{[es] Epistolaridad, voz y reconciliación en documentales norteafricanos recientes}

Resumen. Este articulo toma como punto de partida la noción de Laura Rascaroli de "epistolaridad como argumentación" para analizar cómo los cineastas del norte de África Habiba Djahnine, Drifa Mezenner y Jawad Rhalib utilizan la carta en sus documentales como una estrategia para afrontar la alienación personal en un momento específico de sus historias nacionales. En Lettre à ma sæur (2006), J'ai habité l'absence deux fois (2011) y Le Chant des tortues, une révolution marocaine (2013), trabajando según los modos reflexivos y performativos del documental, los cineastas se convierten en protagonistas de sus proyectos y encuentran su propia voz tras años de represión o exilio. De este modo, finalmente conectan su voz con otras del país como estrategia de reconciliación. El artículo sostiene que estos documentales en primera persona instrumentalizan el dispositivo epistolar para permitir a los cineastas redescubrir sus propias voces y situarlas en sus respectivas historias nacionales de Argelia y Marruecos.

Palabras clave: documental; epistolaridad; reflexividad; performatividad; voz; argumentación

\section{[fr] Épistolarité, voix et réconciliation dans des documentaires nord-africains récents}

\footnotetext{
1 I wish to thank the Social Sciences and Humanities Research Council of Canada for their support of this research.

2 University of Regina (Canada)

E-mail: Sheila.Petty@uregina.ca
} 
Résumé. Cet essai s'inspire de la notion d' « épistolarité comme argumentation» développée par Laura Rascaroli pour examiner comment les cinéastes nord-africaines Habiba Djahnine, Drifa Mezenner et Jawad Rhalib utilisent la lettre dans leurs films documentaires comme stratégie permettant de faire face à une aliénation personnelle à un point spécifique dans leurs histoires nationales. Dans Lettre à ma sœur (2006), J'ai habité l'absence deux fois (2011) et Le Chant des tortues, une révolution marocaine (2013), en travaillant selon des modes documentaires réfléchis et performatifs, les cinéastes deviennent protagonistes de leurs propres projets et trouvent leur voix personnelle après des années de répression ou d'exil. Ainsi, ils relient finalement leur voix à d'autres du pays en tant que stratégie de réconciliation. L'essai soutient que ces documentaires à la première personne utilisent le dispositif épistolaire pour permettre aux cinéastes de redécouvrir leurs propres voix et de se situer dans leurs propres histoires nationales d'Algérie et du Maroc

Mots clé : documentaire ; épistolarité ; réflexivité ; performativité ; voix ; argumentation

Summary. 1. Introduction. 2. 2. Letter to my Sister (2006) by Habiba Djahnine. 3. I Lived in the Absence Twice (2011) by Drifa Mezenner. 4. The Turtles'Song: a Moroccan Revolution (2013) by Jawad Rhalib. 5. Conclusion. 6. References.

How to cite this article. Petty, Sheila (2019). Epistolarity, Voice, and Reconciliation in Recent North African Documentaries. Área Abierta. Revista de comunicación audiovisual y publicitaria 19 (3), 347361. https://dx.doi.org/10.5209/arab.65470

\section{Introduction}

Epistolary enunciation, in all its expressive forms, has long been a cornerstone of identity construction in human existence. Though often referring to letter fiction, epistolarity has taken a firm place in film narratives, with letters functioning to either serve the plot or as voiceover strategies. In her work on epistolarity and essay filmmaking, Laura Rascaroli discusses how certain epistemological strategies germane to prose have been mobilized by filmmakers to function in new ways in film. Her focus on film's formal properties within the essay film provides new insights for "epistolarity and lyricism as argumentation" (2017: 143). Building on the work of Hamid Naficy, she sees these as "disjunctive strategies" that open up "essayistic" spaces of filmic thinking that are not confined to any one genre or specific style (162). Films expressing thinking, and typically delivered by voiceover, are concerned with challenging established notions of reality and foregrounding the constructed nature of the film text itself. This reflexive impulse is often embodied in first-person narration with the filmmaker calling attention to the cinematic apparatus.

Since its publication in 2001, Hamid Naficy's An Accented Cinema: Exilic and Diasporic Filmmaking has served as the key reference for understanding how epistolarity functions in specific diasporic and exilic postcolonial filmmaking contexts. $\mathrm{He}$ is especially concerned with how epistolarity works within an accented context in which "exile and epistolarity are constitutively linked because both are driven by distance, separation, absence, and loss and by the desire to bridge the multiple gaps" (2001: 101). He further argues that no matter what form an epistle embodies, it represents a metaphoric displaced desire and to be with another person or "to reimagine an elsewhere and other times" (101). This implies a sense of recovery - of something lost or repressed - and this makes Naficy's work fundamental when thinking of films 
that arise from expatriation and displacement of the filmmaker who works in alternative production contexts, with migration movement, and exile as common themes (20). Yet, Naficy himself has argued that "the definition of the epistolary mode must be significantly altered" to accommodate new forms and modes of screen media (132). This opens up avenues within both fiction and nonfiction filmmaking to look closely at the "structured articulations of the filmmaker" (Ruby, 1988: 75). Stories told, and arguments unfolded, from specific points of view, provide many ways of knowing and understanding histories.

Rascaroli's work provides many entry points for taking Naficy's arguments in further directions and thinking about "epistolarity as argumentation" in cinema (2017: 143). She draws on the work of Farocki and Hüser (2004) to consider discourses as "a form of narrative" and thus not just about "narrative voice" $(162,144)$. In terms of essay filmmaking, Rascaroli maintains that narrative is "a fundamental component of the argumentation" in essay films (162). She also makes the monumental observation that "the position from which the narrative emanates in epistolary cinema is one of distance" (146). This notion of distance in epistolary films provokes a series of questions around how personal and political histories are staged within time and space and the means of discourse strategies or cinematic devices employed to create meaning. Rascaroli furthers her study of the essay film by exploring how counternarration functions to produce lyricism through fragmentation and gaps, which evoke meaning through affect rather than "story or rational discourse" (144-145). The poetic can be found in the argument and emotion is possible in the documentary form, often considered the paradigm of objectivity and realistic representation.

Expressing reality, or the real, has arguably been the cornerstone of documentary filmmaking since the birth of cinema. However, questions of mediation, voice, point of view, modes and genres, authorship, and representational sovereignty have preoccupied filmmakers and theorists alike through the years. According to Bill Nichols, the 1960s witnessed the domination of observational and participatory modes of documentary whereby filmmaker actively and directly engaged with subject in the participatory and acted as neutral observer in the observational. Films in this latter style had limitations since both the historical past and the filmmaker's stylistic signature were mostly "subordinated to the subject matter" (Nichols, 2016: xii). With the evolution of technology and smaller and more portable and affordable equipment, documentary forms have transformed over the years, becoming much more reflexive and performative in style and form - to the point where some consider "first person accounts" to be as widespread as avant-garde art film (Ulfsdotter, 2018: 144).

In a recent essay on African documentary film, Rachel Gabara astutely outlines how African films have been excluded from most studies of the essay film (2019: 366). The testimonial and reflexive nature of much African documentary cinema and docu-fiction make "a powerful argument against the exclusion of African film from the documentary canon and from studies of reflexive filmmaking" (368). Gabara further argues that "African essay films, both intimate and political", are frequently made "from a position of partial exile" (368). The first person cinematic voice embedded in the structure of much reflexive documentary film takes on complex inflections in the African context. The singular $I$ is often subsumed in the we or $u s$, connecting "inward and outward gazes" (Renov, 2004: 69). The autobiographical is rooted in the local and the national and personal histories are woven into national constructs, exploding the static frame. 
This essay aims to probe how three North African documentary filmmakers deploy the letter as a device to mesh together the personal and the political and come to terms with personal alienation at a specific point in their national histories. Working within reflexive and performative modes of documentary, the filmmakers become participants within their own projects and find their personal voice after years of repression or exile and ultimately connect this voice with others of the nation as strategies of reconciliation.

\section{Letter to my Sister (2006) by Habiba Djahnine}

Algerian documentary filmmaker Habiba Djahnine was born in 1968 in Tizi Ouzou. She has directed several documentary films and written poetry, short stories and magazine articles. She is the co-founder of l'Association Kaïna Cinéma and Association for Cinema and Memory. She has organized and curated film programs for several international film festivals, including Rencontres Cinématographiques de Béjaïa, and at the Goethe Institute. Her documentaries reflect modern Algerian society since the Civil War and propose solutions for the collective development of the nation. In 2007, she founded the documentary film school, Béjaïa Doc, where she trains Algerian youth in all aspects of documentary film production from script to screen to distribution.

In her 2006 documentary, Letter to my Sister (Lettre à ma sœur), Habiba Djahnine pays homage to her sister Nabila who was assassinated by two men in a drive-by shooting during protest marches on February 15, 1995 in Tizi-Ouzou, capital city of the Kabylia region of Algeria. President of the Algerian association, Thighri N'Tmettouth (Cry of Women), Nabila was a staunch promoter of women's rights as well as an advocate of the Berber (Kabyle) language and culture. In the film, Habiba returns to Tizi-Ouzou to speak with the people her sister knew and worked with as well as those who were touched by her advocacy. As she drives her car through the picturesque Kabyle mountain landscapes, she constructs a letter to her deceased sister to counteract the years of silence and distance since her death. Habiba's letterfilm to Nabila becomes a response, in images and words, to a letter Nabila sent to Habiba in 1994, in which she describes the tumultuous state and disintegration of the Algerian nation following the 1991 repression of the Islamic Salvation Front by the ruling National Liberation Front during national parliamentary elections. Various armed groups emerged and carried out a campaign of terror and violence against government supporters. Journalists, artists, writers, activists and foreigners were all targeted during the ten-year period (until 2002) now known as the Black Decade, which witnessed as many as 200,000 fatalities.

The challenge for Habiba is how to name and describe (speak about) the violence that took her sister and how to resurrect an active voice to speak to her dead sister after so many years of silence and terror. Naficy contends that the very structure, organization, themes and visual style of accented filmmakers' works transform "displaced subjects into active agents of their own emplacement" $(2001,98)$. With Djahnine, this applies especially to her themes and structures of emotion that are built into the works' mise-en-scene and but that also arise from the viewer's engagement with them. 
In an interstitial or disjunctive context (to use Rascaroli's terminology), the artist transposes the event or moment to another "displaced" space, or "interstitial moment" as Homi Bhabha would have it (1994: 269). Naficy extends the meaning of being interstitial as, "being located at the intersection of the local and the global" mediating between disparate categories (1999: 134). Subjectivity and identity are determined in these interstitial moments, at the interface of the local and the global, the personal and the political. I would extend the frame of this concept arguing that Djahnine's film demonstrates an innovative blending of the autobiographical, performative, accented, and documentary to create a personal relationship between artist and viewer, thus demanding an active audience in the process of meaning making.

In concert with this theoretical foundation, Djahnine firmly anchors her letterfilm within the Algerian historical frame, measuring distance in terms of memory and emotion. It took her five years after Nabila's death to begin her letter-film, and then another five years to shoot and edit, all the while reflecting on the necessity of speaking up about silenced histories. Habiba's voice-over shapes the narrative, but she also appears on-screen reminiscing with family and friends as she films her letter to her sister.

In Letter to my Sister Djahnine uses landscape shots for moments of pause between scenes, and they are meant to situate the viewer and introduce the location of the following scene. Each scene is bookended by a landscape, often mountainous, that recalls the area where the sisters grew up and were educated. The very first shot of the film is a ten second extreme long shot of a cemetery with a serene mountain vista in the background. The filmmaker then cuts to medium and medium close-up shots of herself and her colleague and cameraperson being greeted by two local men in front of a building, the cemetery and mountains still visible in the background. The men explain that the building was a school where Nabila gave a lecture to a packed room of women. She had promised to return, but unfortunately destiny took over and later, the school was transformed into a mosque with a prayer room. This discussion sets up a mystery for the viewer - who are we talking about? Habiba immediately explains that she is making a film about Nabila and will be back the following weekend to interview the local women. Habiba undercuts the mystery to a certain extent, but the viewer is still left wondering who Nabila was, and thus the quest begins for the viewer to unravel this mystery.

After the local men enter the mosque to pray, the camera fixes its gaze on the building for ten seconds, ending the scene. Habiba thus establishes her sister Nabila as the frame of the film. Nabila opens the film as subject and returns to close the film in the final extreme close-up shots as she discusses how "women have always fought back."3 By opening her film with images of a mosque and prayer room, Habiba forces the viewer to pay their respects to Nabila's soul and to think about atonement for past sins. The camera's/Habiba's gaze is meant for Nabila - who would immediately recognize the landscape - words and voice-over are not always necessary in the letterfilm, yet when they are used, they are of "central importance" to the film (Naficy, 2001: 120).

This film for and about her sister acts as a form of shriving of trauma, violence and silence, and an excavation of the repressed, the ignored, the put away, the oc-

Translations of original quotations are mine. 
cluded... a memorialization process that Djahnine herself calls "dis-alienation." Here, this is not about the epistolary crossing of physical borders but about communication between the living and the dead. Nabila was killed in a drive-by shooting and interestingly, Habiba begins narrating the letter-film to Nabila in her car driving in the mountains and into the cities as though Nabila is with her in the car (Image 1):

Ten years after your assassination and it is only today that I can revisit those moments. To speak about you is to speak about all the women in the world who refuse to give up their dignity [...] How can we live with these wounds? How can we vomit our fear and hate of the assassins? I can barely distinguish mourning from madness. Into what kind of silent abyss have they thrown you?

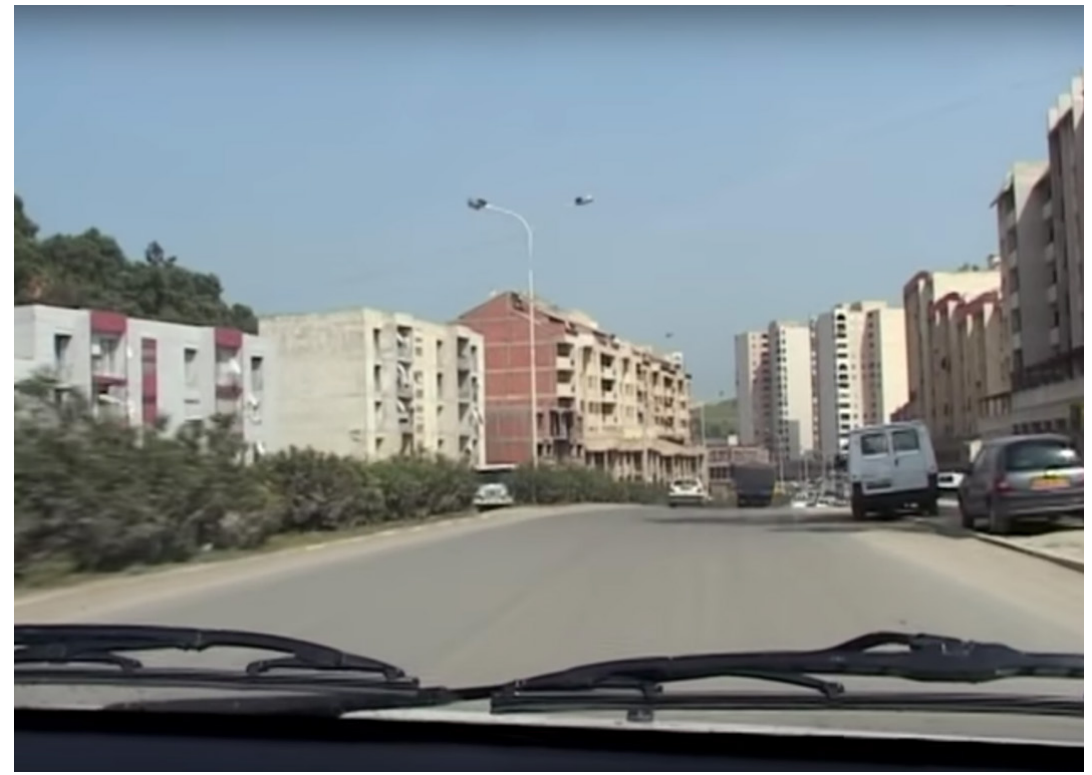

Image 1. Letter to my Sister (Habiba Djahnine, 2006). Source: Screenshot.

Habiba's voice-over is eventually accompanied by the melancholy chords of a stringed instrument, "I am taking you to Béjaïa. Our parents are waiting for us there. What can I say? I am speaking to you." There is a disjunctive relationship between voice, interiority and identity in the film, which Stefanie Van de Peer has previously argued in the case of Jocelyne Saab's films, is simultaneously selfreflexive and non-synchronous (2018: 78). This speaks to the ambiguity of the film's title, Letter to my Sister. Which letter and which sister? We do not see Habiba actually writing a letter and reading it. We assume she is responding to a letter written to her by Nabila the year before her assassination. We also assume that because she is the filmmaker, she is composing the letter in her mind and narrating it to her dead sister as she drives through the mountains. The narration is very self-reflexive and signifies her painful memories of her sister's demise, and yet, the way the letter is spoken over the driving point-of-view shots raises "ontological doubt" about temporality, location, and voice in the film (Van de Peer, 2018: 78). Is Habiba driving as she makes her film in the present, or is this the journey with 
Nabila's coffin ten years ago? Habiba's voice-over provides an ideological thread to the image track's point-of-view driving shots through mountains and towns. The spatial and temporal points of reference are her sister and their relationship, from which a melancholic form of poetry is born.

Oral cultural expressions such as poetry, proverbs and songs are very important to the Kabyle culture of Algeria, to which the Djahnine family belong. Habiba visits the elderly Kabyle women who knew Nabila and they prepare a meal for her and dedicate a song to her that they improvise on the spot in memory of Nabila. The women, for whom poetic creation is spontaneous, transform the words into an homage to Habiba for keeping the memory of her sister Nabila alive: "O my soul, improvise a poem. For her, so dear to my heart. Today her sister has come. Listen to our message. She has come to ask, what her sister did. Her soul is in paradise. She who stands up for women's rights; Today we remember her, as if she is here with us" (Image 2) As the final words are sung, the image track shifts from medium shots of the small group of women singing to a long shot of a solitary Kabyle woman wending her way down a road into the background. The shot lasts ten seconds, allowing the viewer the time to ponder the significance of the women's words. The singular and the collective are sutured as Habiba is simultaneously spectator and recipient of the homage (Maazouzi, 2013: 4-5).

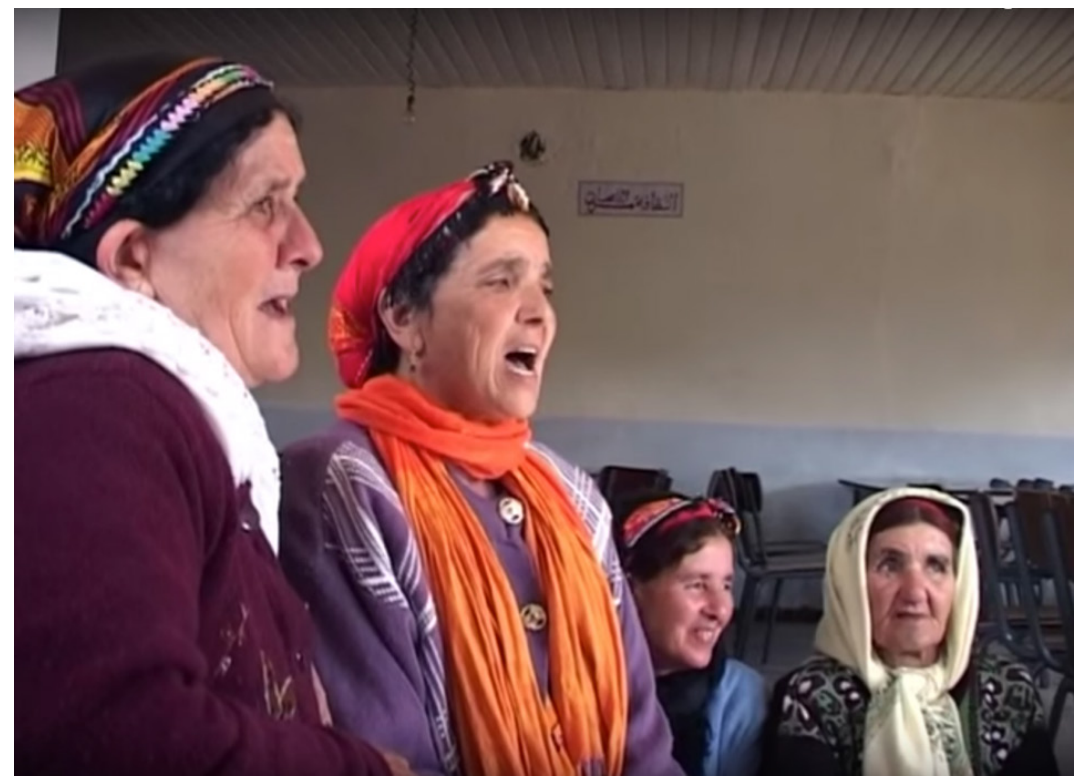

Image 2. Letter to my Sister (Habiba Djahnine, 2006). Source: Screenshot.

In a recent article on the work of Habiba Djahnine, Djemaa Maazouzi argues that as the village women improvise the achewiq (song improvised in memory of someone) their collective voice joins with the other women's voices in the film to provide a "polyphonic" description of the incredible heritage that Nabila bestowed on the women (2013: 5). Maazouzi contends that the achewiq acts as a form of suture to the pain caused by the assassination: physical pain suffered by Nabila and emotional and psychological pain suffered by Habiba, her family and friends. The present, embodied in the women's performance for the camera, is infused 
with the ancestral past. Thus, orality, and oral tradition in the case of Letter to my Sister impact the letter-film's "formal, stylistic, and thematic systems" (Naficy, 2001: 121). The film ends with tributes by women friends and family members - a collective response to Nabila's legacy and a means for all to participate in the letter -film to my sister. The film ends in extreme close-ups of Nabila gazing outward at the camera in direct address to all Algerians as she exclaims that women are also human beings!

\section{I Lived in the Absence Twice (2011) by Drifa Mezenner}

Algerian director, Drifa Mezenner has used documentary form with infusions of epistolary inflections to create a lyric essay film that is both personal and political. Rascaroli writes that "far less critical attention has been paid to the definition of the lyric essay film than to the literary one" (2017: 156). She argues that "poetic fragmentariness," reflexivity, metaphor and "creative nonfiction" are all potential features of the lyric essay film (156). These were all present to some extent in Letter to my Sister. Mezenner studied graphic arts and English literature, and works as a graphic designer. She was a student of Habiba Djahnine in the Béjaïa Documentary Workshop in 2011, and under her guidance she produced her first short film, I Lived in the Absence Twice (J'ai habité l'absence deux fois), which has been selected for several international film festivals and has won awards. I Lived in the Absence Twice deals with the impact of absence on the filmmaker, and the effects of absence and disaffection on Algerian youth following the Civil War, as well as on Mezenner's own family (Lamri, 2014).

The film is set in Algiers where Mezenner revisits her old neighbourhood of Kouba to excavate memories of the past. Her brother Sofiane is central to the narration of separation, pain and absence because he is the family member who, in 1992, had fled the country's turmoil during the Civil War and immigrated to Britain in search of a better life. Details of his departure - legal or illegal - are left out of the film, as though the filmmaker is deliberately creating several layers of absence. These layers of absence become layers of distance, in Rascaroli's terms (2017: 163).

The film opens with an extreme low angle shot of the sky as birds fly around. The camera pans down to focus on trees and a garden. A blunt cut transitions the image to a medium shot of a man in the garden with his back to the camera. He walks toward the background, still refusing to face the camera as Mezenner asks him in voice-over, "Dad, what has changed since 1992?" He keeps walking, refusing to speak or address the camera. She continues, "You, who made the liberation war. After experiencing the Dark Decade, how do you find Algeria now? Is the situation better than before? Dad?!" He finally retorts, "Do not talk to me." He only turns around to face the camera when he exclaims that the liberation war was not the same as the civil war. He is bitter about Sofiane's exile and about Algeria's current situation. When Mezenner explains that he was seeking freedom, her father retorts, "Freedom is the one you build with your family." After they share a joke about exile, the filmmaker adds a layer of distance - a reflective stance, as she frames her father in a medium shot facing off-screen right and addresses the spectator: "This is my father [...] and the girl behind the camera is me: Drifa." As she pronounces her name, the image cuts to a close-up of her directly addressing the camera/spectator. She continues, "I was born and grew up in Kouba (El 
Kobba) and am still living there." These close-ups give way to images of the neighborhood as Mezenner explains that many youth from this area emigrated to the United Kingdom. Her brother Sofiane is one of them and he has been gone for almost twenty years. During this period, the two leaders of the Islamist political party, Islamic Salvation Front, preached in the neighborhood's main mosque, attracting many spectators from all over Algiers who were disaffected by national state discourse. Drifa's voiceover continues as she presents her other brother, Hamoudi and her mother (who is still waiting for Sofiane) and explains that the year Sofiane left is the year they moved to another house in another neighborhood. Like Habiba Djahnine, Mezenner returns to her childhood neighborhood to excavate memories.

Mezenner explains that when she informed Sofiane about her film project, he did not want to be filmed (like the rest of the family) and preferred to write her a letter in English explaining his exile. As he begins his narration in accented English, swirling images of treetops dominate the frame as though signifying turbulence and chaos - a metaphor for 1990s Algeria: "Sister, in order to do my story justice, you have to go back a little. To understand the present time and thus conclude some sort of picture, I'm going to tell you the story as I remember it. But let us say, as unclear as it was, we were completely oblivious..." As he pronounces the word, "Oblivious" Mezenner's voice-over in Arabic is superimposed over Sofiane's, adding a further layer of distance/absence as the spectator is forced to negotiate between the two competing voices in different languages. She explains: "In his letter, Sofiane told me what he still remembers. He said we were completely oblivious to how fortunate it was." As she continues the narration, Sofiane's voice disappears, and she continues to summarize his letter. Sofiane's voice returns in the sequence of close-up shots of his mother making bread. He confesses that he remembers everything very clearly as if it was yesterday. He had planned everything carefully but could not tell his family. At breakfast, his mother gave him fifty dinars and he left Algeria for a better life. His letter continues later in the film, laid over an image track of pointof-view shots of Mezenner driving through Kouba. He concludes (in English) that until Algerians stop leaving for a better life, "then I can tell you Algeria is back," as Mezenner simultaneously speaks the same words in Arabic. In a later sequence, she addresses him directly in voice-over while his image disappears from the frame (Image 3): "Sofiane, you migrated and were exiled abroad. We stayed here and were exiled inside us. Your absence made those who are present seem absent." All the seasons passed, "and me, I lived in the absence twice." The film ends as Mezenner's mother composes a poem for the absent Sofiane. She sits facing the camera in direct address medium shots. Her voice-over sings the poem as she sits in silence and the screen fades to black and the credits roll (Image 4). The melancholic tone is highly reminiscent of that in the achewiq addressed to Habiba Djahnine and dedicated to her sister, Nabila.

The layering of absences and use of voice-over recall Laura Marks' theoretical model of enfolding (forgetting or hiding) and unfolding (remembering) of knowledge. According to Marks: "the past persists, enfolded in virtual form, and some of its facets may unfold to some degree in the present" (2015: 11). Stefanie Van de Peer takes Marks' idea further by suggesting that "sensitive information [...] can be revealed and liberated, or unfolded through the act of 'listening' and 'seeing' in the audiovisual art of documentary" (2018: 25). Mezenner employs aspects of epistolarity such as the voice-over narration of letter reading to enfold the reasons for Sofiane's 
departure and exile, but also to unfold her own memories of the past twenty years. Interestingly, the past is exhumed while visually depicting images of the present.
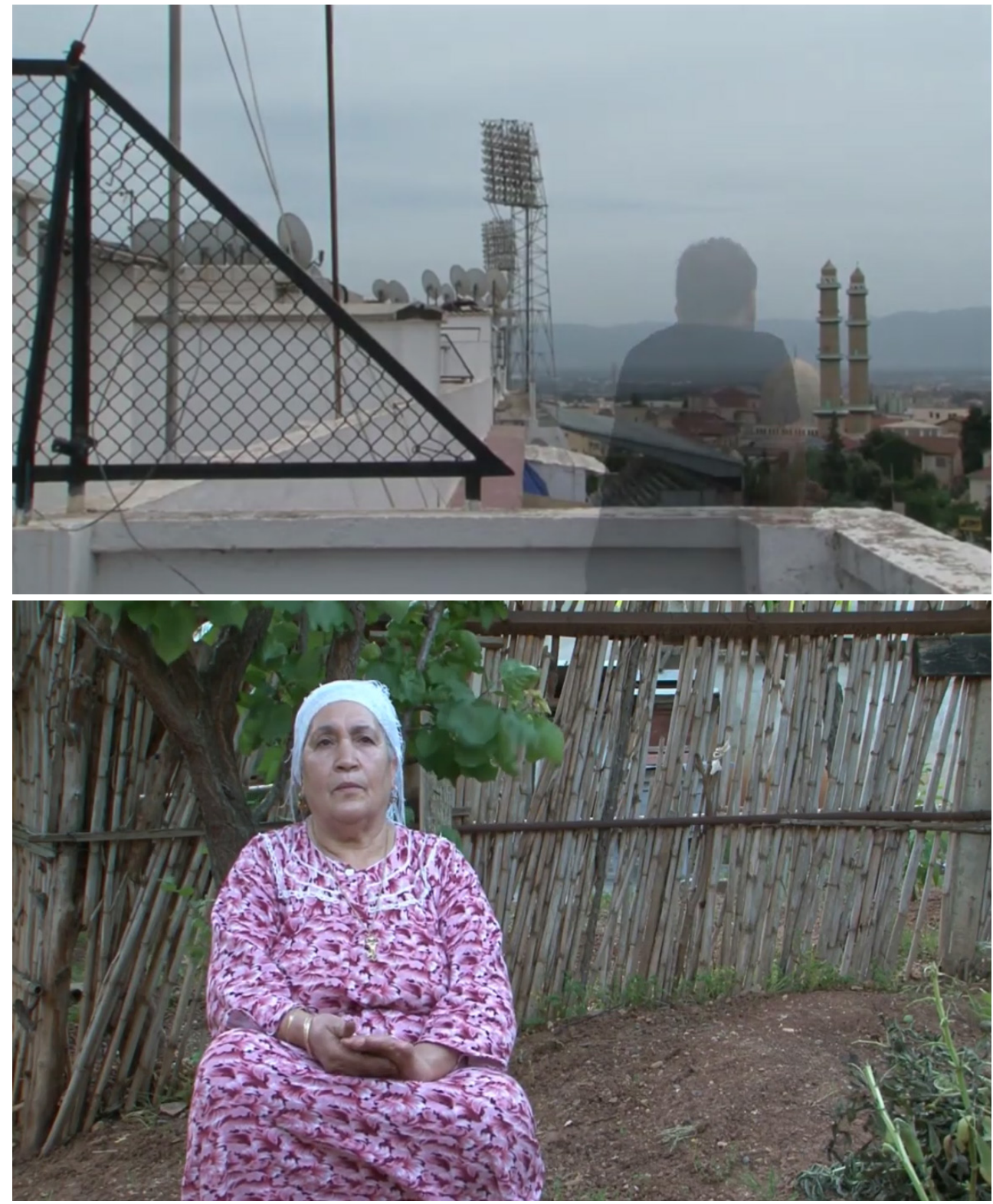

Image 3 and 4. I Lived in the Absence Twice (Drifa Mezenner, 2011).

Source: Screenshot.

The personal and the political are carefully intertwined and raise important issues of generational conflict in contemporary Algerian society. Drifa expresses her personal experience of the civil war and that of her siblings and friends in contrast to her father's anger and silence regarding Sofiane's choice to immigrate to a perceived easier (although clandestine) life in England. Drifa's personal history, like that of 
Sofiane and the rest of her family members, is part of the larger political and historical tapestry of the nation.

\section{The Turtles'Song: a Moroccan Revolution (2013) by Jawad Rhalib}

In a somewhat similar vein as that of Mezenner's reflexive documentary, MoroccanBelgian filmmaker Jawad Rhalib has used documentary form for explorations of Moroccan history and culture, providing exposure through cinematic expression to those who have been silenced by history and politics. Born in Morocco in 1965, Rhalib grew up in Belgium and lives and works in both countries. He both writes for journals and newspapers and directs socially-conscious films focussed on human rights issues, globalization, and sustainable development issues. His feature documentary, The Turtles'Song, a Moroccan Revolution (Le Chant des tortues, une révolution marocaine, 2013) is set against the backdrop of the Movement of February 20, 2011, when the Arab Spring uprisings in Tunisia and Egypt had spread to Morocco. As a result, Moroccans protested for dignity, freedom of speech, social and political change, and an end to the culture of fear which had permeated the kingdom since, and especially during, the Lead Years of King Hassan II.

The narrative is organized into three chapters, similar to a book's structure and personal memories are recounted through interviews, archival documents and live footage of demonstrations. Rhalib plays a self-reflexive role in the film with his voice-over and visual presence in shots throughout the film shaping the content. He anchors the narrative clearly within Moroccan national history when he narrates, over a map of the kingdom:

This is the kingdom of Morocco [...] bordering between Europe and Africa. Since 1631 the country has been governed by the Alawite Dynasty whose members claim to be direct descendants of the Prophet Mohammed. On March 2, Morocco gained independence and Mohammad V assumed the title of king in August 1957. $\mathrm{He}$ is considered by many to be the father of the modern Moroccan nation. On February 26, 1961, he died during routine surgery and Hassan II succeeded him to the throne. For three decades the Moroccans would be subjected to measures of austerity, repression, arbitrary arrests and torture. The reign of Hassan II, known as the "Lead Years," was witness to tens of thousands of victims [...] killed, maimed, imprisoned, made to disappear or forced into exile.

The initial presentation appears to be objective and in expository mode, as Rhalib narrates, avoiding the first-person pronoun. His tone of voice, however, takes on a terse edge as he says the words, Lead Years, and the map dissolves into archival black and white photos of secret sites of police interrogation and torture. Rhalib embraces the first-person voice when he declares that he will go out in the community "to see and give voice and exposure to a nation who is finally finding its voice, a nation who defies fear." As he takes on the first-person voice, we also glimpse physical images of him within the frame and diegesis - object and subject become one and silenced voices are afforded time and space.

In this film, the epistolary impulse is one of protest and activism and two very specific examples of epistolary form stand out. In the first, the filmmaker creates a 
metaphor linking his fate to that of writer/journalist and former political prisoner, Khalid Jamaï, who reads passages of his novel, 1973, Présumés coupables (2003), at various points throughout the film. In the film, Jamaï acts as reporter and embodiment of the Lead Years experiences, and, as such is the teacher and mentor to the Internet and Facebook generation who want immediate social and political change. Jamaï is the wise teacher giving the history lesson and contextualizing for these youth the concept of sustained revolution through the metaphor of the Moroccan turtle rather than the Egyptian or Tunisian rabbit.

During the Lead Years, journalists were arbitrarily arrested, detained and tortured. Heavy censorship of all media was the norm. Jamaï, a journalist for the nationalist (Istiqlal or Independence Party) French language newspaper, L'Opinion, was incarcerated for five months in 1973 without a trial for allegedly authorizing a photographer to take a photo of one of the royal family's children while in a Rabat street. As he begins to read, Jamaï is depicted in a slightly-high medium close-up shot facing the camera, as he sits at his desk, head buried in his novel. The image is in black and white but color bleeds in as Jamaï's voice-over begins reading from the novel. The next shot is a close-up of the page being read, as if Rhalib wants to reassure the viewer that although these are Jamaï's words and not his own, this individual experience of history could very well be a collective one. Jamaï's performance is a "ritual of communication" whereby "diegetic characters and filmmakers seek to redress a historical wrong by appealing to spectators' sense of morality and justice" (Naficy, 2001: 114). Naficy terms this structure, "epistolary communitarianism," and although actual letters might not be involved, the films themselves "are often made under the regimes of erasure and desire that are similar to the letter-films, and their diegetic characters address the audience directly, using the film itself as an epistle" (214).

The shot that follows is a medium close-up of Jamaï facing the camera and musing: "Fear was a structural element of Hassan II's regime. But worse than that was the fear of being afraid, and of the unknown. It was a world in which we felt we were always being watched [...] always under heavy surveillance." Jamaï is positioned frame left, and on frame right is a prominently-displayed newspaper clipping penned by Jamaï and titled, "Lettre Ouverte au Roi Mohammed VI" (Open Letter to King Mohammed VI) (Image 5). The letter takes up the issues and demands of the Feb. 20, 2011 Movement and would have been unthinkable under the reign of Hassan II. Jamaï still believes that not much has changed in Morocco and that the king has monopolized and consolidated his executive, legislative and judicial powers as "Commander of the Believers," leaving parliament mostly out of the picture. According to Jamaï, the king continues to enjoy supreme authority over every decision affecting Jamail's life and that of his children and grandchildren; although it could be argued that Jamaï is ignoring that separation of power should be understood from two different perspectives: Islamic public law and modern constitutional law. In an open letter posted November 29, 2016 on the Arabic site, Hespress, Jamaï explains that he continues to write to the king in the hopes that one day concrete reforms will occur (Jamaï, 2016). 

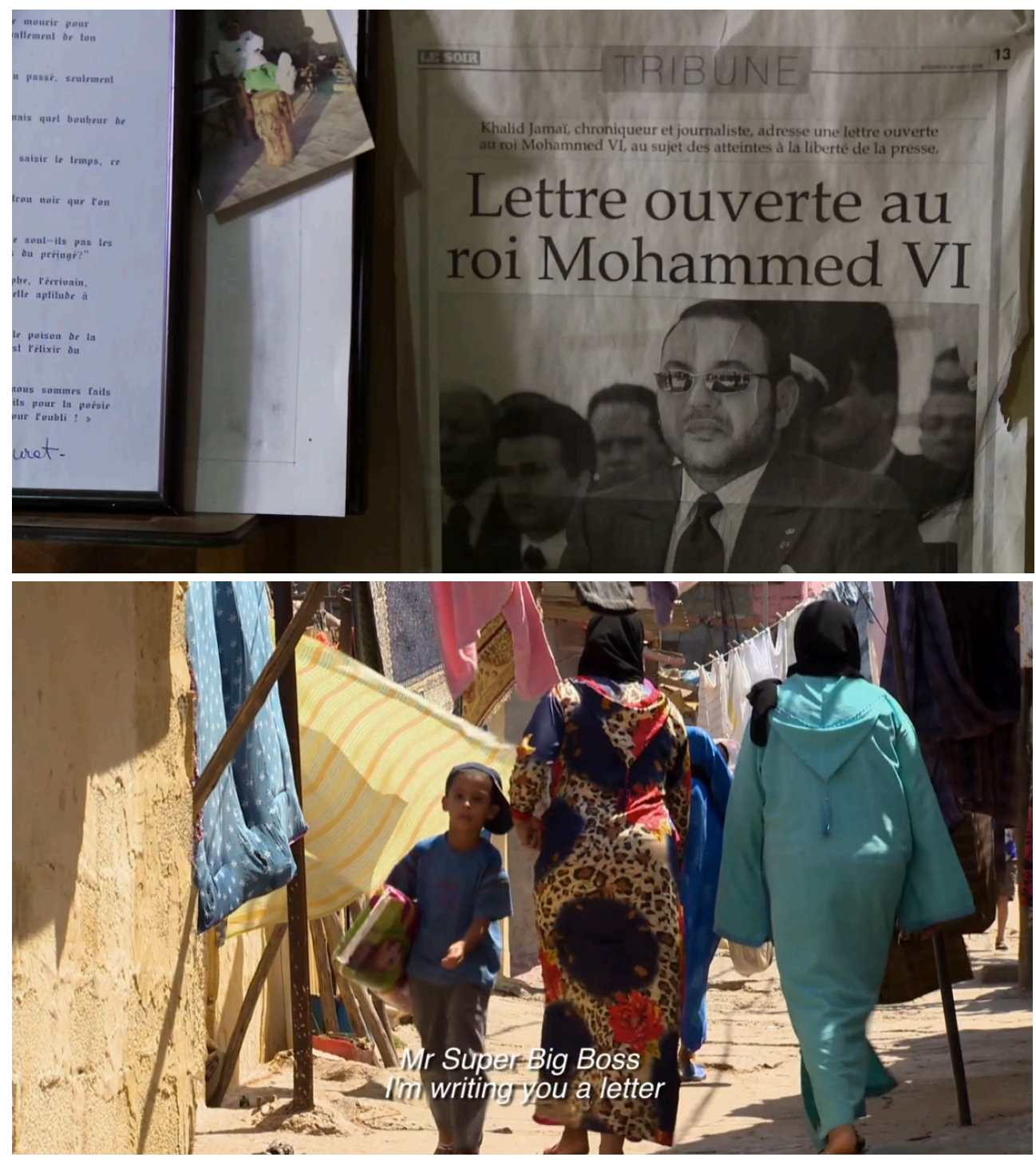

Image 5 and 6. The Turtles'Song, a Moroccan Revolution (Jawad Rhalib, 2013).

Source: Screenshot.

The second example of epistolary form occurs through the performance of rap songs by the musical fusion group Hoba Hoba Spirit, a band based in Casablanca. A music track of their song, "Super Caïd" (2007) is laid over images of poverty and despair and posters denouncing corruption as the singers rap, "Monsieur le Super Caïd, I'm writing you a letter which I hope you will read after Eïd [...] I am hoping you will grant me a life certificate and may God glorify you" (Image 6). Song transitions to speech acts as ordinary Moroccans take to the podium in the newly-created speaker's corner for free speech, the Casablanca Agora.

The filmmaker enfolds layers of meaning through irony, parody and metaphor. Naficy writes: "Parody has become a major performative strategy in our age, dubbed 
the "age of irony"'. He cautions that nothing can be taken for granted and that even heroes can be "deconstructed and deflated" $(2001 ; 278)$. The risk with irony is that it can be misconstrued and offer the impression that it can take the place of serious political action However, for the viewer who successfully unfolds the layers of meaning of Hoba Hoba Spirit's audio letter, layered over the visual track of images of Moroccan despair, the result is rewarding. For example, "May God glorify you," is a phrase normally used to address someone in high power. So, who is the Super Caiid, and is the song a further petition (beyond Jamaii's open letter) to the king on the part of the filmmaker, Rhalib, imploring Mohammed VI to take better care of his thirty million subjects? Naficy contends: "the very fact of addressing someone in an epistle creates an illusion of presence that transforms the addressee from an absent figure into a presence, which hovers in the text's interstices" (2001: 103). From these, the film unfolds the question of who is responsible for the future of Morocco. While the filmmaker concludes that everyone is responsible for building a better future, it is useful to recall Jamaï's open letter to the king which outlines how, within the constitution, every citizen of the kingdom has the right to hold the king and the government to account for the kingdom's and the people's wellbeing. Hoba Hoba Spirit end the film rapping the revolutionary poem, "The Will to Live," written in 1933 by the Tunisian Abou el Kacem Chebbi, and which became the revolutionary slogan of the Arab Spring uprisings.

\section{Conclusion}

I began this essay with the goal of taking Laura Rascaroli's notion of "epistolarity as argumentation" (2017: 143) to probe how North African documentary filmmakers Habiba Djahnine, Drifa Mezenner, and Jawad Rhalib deploy the letter in their reflexive and performative documentary films as a strategy to come to terms with personal alienation at a specific point in their national histories. In Letter to my Sister, Habiba Djahnine crafted a letter-film to speak the violence of the Algerian Civil War period and overcome it to find a way forward in post-civil war Algeria. The letter-film also provided a voice for her dead sister to respond to the violence enacted on her and to continue her work by speaking (posthumously through the letter-film) to all Algerian feminists. In I Lived in the Absence Twice, Drifa Mezenner creates an epistolary relationship with her absent brother in order to come to terms with his absence from the family and exile from Algeria. This double absence creates yet another absence within her very being that she attempts to reconcile within and alongside a society torn apart by civil war, terrorism and exodus. In The Turtles' Song: a Moroccan Revolution, Jawad Rhalib depicts how, in post-Arab Spring Morocco, newspaper letters and rap song letters are just some of the ways in which Moroccans are gaining voice and overcoming the fear of speaking out.

Each film is a first-person film in which the letter functions as an integral plot device to allow the filmmaker to rediscover their own voice and place within their own national histories of Algeria and Morocco. What began with personal silence and despair evolved into collective voice and activist expression within the essay film canon. 


\section{References}

Bhabha, Homi. (1994). "Frontlines/Borderposts.” In Angelika Bammer (ed.), Displacements: Cultural Identities in Question. Bloomington: Indiana University Press, 269-72.

Farocki, Harun and Hüser, Rembert. (2004). "Nine Minutes in the Yard. A Conversation with Harun Farocki.” In Thomas Elsaesser, (ed.), Harun Farocki. Working on the Sightlines. Amsterdam: Amsterdam University Press, 279-314

Gabara, Rachel (2019). "From Ethnography to Essay: Realism, Reflexivity, and African Documentary Film." In Kenneth W. Harrow and Carmela Garritano (eds.), A Companion to African Cinema. First Edition. New York: John Wiley \& Sons, Inc., 358-78.

Jamaï, Khalid (2016). "POLÉMIQUE - Khalid Jamaï explique dans une lettre ouverte pourquoi il a souvent interpellé le roi du Maroc..." Article19.ma, 1st December Retrieved from http://article19.ma/accueil/archives/55345

Lamri, Rachida (2014). "Arts \& Culture | Interview | Drifa Mezenner: 'I lived in the absence twice"". Ceasefire. 1st April. Retrieved from https://ceasefiremagazine.co.uk/interview-drifa-mezenner-i-lived-absence-twice/

Maazouzi, Djemaa, Djemaa (2013). “Néant et lumière', l'Algérie possible de Habiba Djahnine”. Nouvelle Revue Synergies Canada, 6, 1-14. Retrieved from https://journal.lib. uoguelph.ca/index.php/nrsc/article/view/2870/3143

Marks, Laura U. (2015). Hanan al-Cinema: Affections for the Moving Image. Boston: The MIT Press.

Naficy, Hamid. (1999). "Between rocks and hard places: the interstitial mode of production in exilic cinema". In Hamid Naficy (ed.), Home, Exile, Homeland: Film, Media, and the Politics of Place. New York and London: Routledge, 125-147.

Naficy, Hamid (2001). An Accented Cinema: Exilic and Diasporic Filmmaking. Princeton, NJ: Princeton University Press.

Nichols, Bill. (2016). "Foreword”, In Daniel Marcus and Selmin Kara (eds.), Contemporary Documentary. Oxon and New York: Routledge, xi-xvii.

Rascaroli, Laura. (2017). How the Essay Film Thinks. New York: Oxford University Press.

Renov, Michael. (2004). The Subject of Documentary. Minneapolis: University of Minnesota Press.

Ruby, Jay. (1988). "The image mirrored: reflexivity and the documentary film." In Alan Rosenthal (ed.), New Challenges for Documentary. Berkeley: University of California Press, 64-77.

Ulfsdotter, Boel. (2018). "The Memories of Belleville Baby: Autofiction as Evidence". In Boel Ulfsdotter and Anna Backman Rogers (eds.), Female Authorship and the Documentary Image: Theory, Practice and Aesthetics. Edinburgh: Edinburgh University Press, 144-58.

Van de Peer, Stefanie (2018). Negotiating Dissidence: The Pioneering Women of Arab Documentary. Edinburgh: Edinburgh University Press. 